\title{
Comparison between the SPD and the SPDS Methods for Segregating Generation Advancement in Soybean
}

\author{
Deonisio Destro* , Henrique Stoco Bizeti, Leandro Anderlin Garcia, Inês Cristina de Batista \\ Fonseca, Ricardo Montalván and Édison Miglioranza \\ Department of Agronomia; Universidade Estadual de Londrina - UEL; C. P. 6001; 86051-990; Londrina - PR - \\ Brazil
}

\begin{abstract}
The purpose of this work was to compare the SPD (Single Pod Descent) and SPDS (Single Pod Descent with Selection) methods for segregating generation advancement in soybean breeding. Sixteen populations derived from crosses among Japanese and adapted Brazilian soybean were used. The traits, number of days to flowering (NDF) and to maturity (NDM), plant height at flowering (PHF) and at maturity (PHM), and individual plant yield (IPY) were assessed. The populations obtained by SPDS showed values close to the variation in the populations obtained by SPD. Regression through the origin showed that both methods were equivalent for NDM in the $F_{3}$ generation and for NDF in the $F_{4}$ generation. For all other trait/generation combinations, SPDS yielded superior means. Therefore, it was preferable to use SPDS because it allowed the advance of generations with smaller population size.
\end{abstract}

Key words: Glycine max, breeding methods, food type soybean

\section{INTRODUCTION}

Soybean [Glycine $\max$ (L.) Merrill] is an important crop in Brazil due to its large cultivation area in different regions of the country. The importance of soybean worldwide is due mainly to its high oil and protein contents (Marega Filho et al., 2001). Cross-breeding between pure lines is performed in order to obtain new cultivars, usually more productive and/or with other desirable characteristics. The segregating generations may be conducted by any of the methods frequently used for self-fertilization crops: pedigree, bulk, single seed descent (SSD) or single pod descent (SPD). The SSD method is implemented by collecting a single seed from each plant to form the next generation (Brim, 1966). When the number of $F_{2}$ plants is limited, a method derived from SSD can be used, in which each plant is represented by multiple seeds in all the segregating generations (Fehr, 1987). To obtain a sample of seeds in which all plants are equally represented in later generations, a pod with 3 seeds is cultivated, characterizing the SPD method. This method is an easy and economic alternative for the advance of segregating populations, aiming at a quick homozygosis.

A modification of the SPD method is the SPDS method (Single Pod Descent with Selection). It is similar to SPD, but no pods are collected from agronomically inferior plants in the $F_{2}$ to $F_{4}$ generations. Such selection in segregating generations must be performed only for qualitative or quantitative traits with high heritability, and which have high phenotypic and genotypic correlation with grain yield.

\footnotetext{
* Author for correspondence
} 
In studies comparing the main advantages and disadvantages of several generation advancement methods, Toledo et al. (1994) concluded that the methods had similar probabilities to generate descendants with high grain yield when the sample of genetic variability was comparable. This explains the preference for simpler methods, such as the SPD. In order to obtain plants with a long juvenile period and based on the information that the inheritance of this character is simple (few genes involved) and that there is the possibility of selecting genotypes with this characteristic under short day conditions, the following procedure has been used in the breeding program at the National Research Center of EMBRAPA - Brazilian Company for Agronomic Research - in Londrina, PR (Kiihl and Garcia, 1989): a) genotypes used in crosses are planted in November and December, to coincide with the flowering period; the crosses are carried out in January and February and the seeds are harvested in March or April; b) the $F_{1}$ are cultivated during the winter in greenhouses with supplementary light, for 20-30 days, to avoid early flowering; c) the $F_{2}$ populations are grown in the field, with early October planting. One pod is collected per plant, but only from plants with a long juvenile period (SPDS method); d) the $F_{3}$ populations are grown during winter, from which one pod per plant is harvested (SPD method); e) the $\mathrm{F}_{4}$ populations are planted early in October, and the best plants with long juvenile period are harvested individually; f) $F_{5}$ progenies are grown also in early October planting, and the best lines are selected.

The Brazilian cultivars are not adequate for direct human consumption. To obtain such cultivars, industrial soybean is usually crossed with food type genotypes. Pure lines of food type soybean were developed in Asia (approximately $40^{\circ} \mathrm{N}$ latitude) and showed a short juvenile period. When they are cultivated in Brazil, where the days are shorter due to low latitude, there is a early flowering. Such fact, associated with the determinate growing habit reduces the number of nodes, plant height and grain yield (Manfredini et al., 1998). Destro et al. (1994) observed that the soybean introduced from Japan had the disadvantage of having low physiological seed quality which reduced the germination and emergence capacity of the seeding in the field.

The purpose of this work was to compare the SPD and SPDS methods for segregating generation advancement in soybean cross-breeding for human consumption with industrial soybean.

\section{MATERIAL AND METHODS}

The experiment was developed and conducted at the Londrina State University (UEL) School Farm (Londrina, PR, Brazil), located at $23^{\circ} 22^{\prime} \mathrm{LS}, 51^{\circ}$ $10^{\prime} \mathrm{LW}$ and 585 meters above sea level on a structured purple soil, classified as eutrophic. The 16 populations used were supplied by the UEL Soybean Breeding Program (Table 1). Generations advance were accomplished through SPD and SPDS methods.

Table 1 - Assessed segregating populations.

\begin{tabular}{cc}
\hline Population & Cross \\
\hline 1 & Paranagoiana X F82-5722 \\
2 & Paranagoiana X F82-5782 \\
3 & Paranagoiana X F83-7843 \\
4 & Paranagoiana X Sel Stwart \\
5 & Paranagoiana X Tadasha \\
6 & BR-27 X Late Giant \\
7 & BR-27 X Kitamusume \\
8 & BR-27 X F82-5722 \\
9 & BR-27 X F82-5782 \\
10 & BR-27 X F83-7843 \\
11 & BR-27 X Natto \\
12 & BR92-15360 X Tambagura \\
13 & BR92-15360 X F82-5722 \\
14 & BR92-15360 X F82-5782 \\
15 & BR92-15360 X F83-7843 \\
16 & BR92-15360 X Wilami \\
\hline
\end{tabular}

In the $F_{2}$ generation, a pod containing three seeds was collected from all the population plants for generation advance and another pod was reserved, using the SPD method. The same procedure was used only on plants with superior agronomic worth (AW), characterizing the SPDS method. The agronomic worth was visually analyzed at maturity. This grade scale varied from one to five, in which one corresponded to a bad plant and five to an excellent one. It represents a visual rate of the plant global merit for a series of adaptative traits such as: number of pods; plant strength and health, resistance to lodging, shattering resistance, and reducted leaf retention after maturity (Guerra et al., 1999). The SPDS method caused a reduction in the population size by the elimination of inferior genotypes, before time and effort were spent on reaching homozygosis. Approximately $15 \%$ of the total of plants used initially remained. It is important to emphasize that the selection occurred only in generation $\mathrm{F}_{2}$, as in the procedure used by Kiihl and Garcia (1989). 
In the $F_{3}$ and $F_{4}$ generations, the seeds for generation advancement by the SPD and SPDS methods were sown separately to allow their comparative evaluation. In the agricultural year of $1997 / 98$, the $F_{3}$ populations were sown in the field on December 22, in six-meter rows for the SPD method and two-meter rows for the SPDS method. The spacing between the rows was 0.9 meter. Three seeds per plant were harvested from the $\mathrm{F}_{3}$ populations for advance to generation $\mathrm{F}_{4}$, both for the SPD method and the SPDS method. In the agricultural year of $1998 / 99$, the $F_{4}$ populations were sown in the field on December 10. Each population was represented by a five-meter row for the SPD method and a one-meter row for the SPDS method. The spacing between lines was 0.9 meter. The sowing density was 10 plants per linear meter.

In the two agricultural years, the preparation of the soil was conventional, with one plowing and two harrowing. Fertilization was done with $400 \mathrm{~kg} / \mathrm{ha}$ of NPK, in the 8-28-16 formulation. After the sowing, the fields were hand hoed to control weeds. Insecticides were used to control soybean leaf-shedding caterpillars (Anticarsia gemmatalis) and soybean bugs (Nezara viridula).

In $\mathrm{F}_{3}$ and $\mathrm{F}_{4}$ generations, all plants were harvested and thrashed individually. Five quantitative characters were assessed to compare SPD and SPDS generation advance methods. These characters were: a) number of days to the beginning of flowering (NDF) corresponding to the period between the sowing and the opening of the first flower $\left(R_{1}\right.$ stage of the scale of Fehr and Caviness, 1977); b) plant height at the beginning of flowering (PHF) which corresponds to the distance in $\mathrm{cm}$ measured between the soil level and the most distal inflorescence insertion on the main stem, assessed at the $\mathrm{R}_{1}$ stage; c) number of days to maturity (NDM) which corresponds to the period between the sowing and the day in which approximately $95 \%$ of the pods appeared to be mature $\left(\mathrm{R}_{8}\right.$ stage); d) plant height at maturity (PHM) which corresponding the distance $(\mathrm{cm})$ measured from the soil surface and the farthest flower bud on the main stem, evaluated at the $\mathrm{R}_{8}$ stage; and e) individual plant yield (IPY), evaluated after thrashing and by the grain weight. The data were collected in grams per plant, but only in the $F_{4}$ generation. Still were assessed costs of labor, breeder's work and experimental area, but these data are not presented here.
Correlation estimates, means and coefficients of variation of each population were used to compare the methods. Correlation estimates from individual plants among the traits were obtained as described by Mode and Robinson (1959). The significance of the correlations was tested by the $t$ test, with $\mathrm{n}-2$ degrees of freedom (Venkovsky and Barriga, 1992). The coefficients of variation (cv) were obtained by:

$$
\mathrm{cv}=(\text { standard deviation } / \text { mean }) * 100 .
$$

The mean of each population still was used in the analysis of regression. The regression procedure, which fits a straight line passing through the origin (Bussab, 1990), complemented with the test for hypotheses $\mathrm{H}_{0}: \beta=1$ and $\mathrm{H}_{1}: \beta<1$ was used. This procedure evaluated the possibility of substitution of the SPD by the SPDS method in the generation advancement of soybean segregating populations. Whenever hypothesis $\mathrm{H}_{0}$ was accepted by the test, it meant that the methods were equivalent and whenever it was rejected in favor of $\mathrm{H}_{1}$, it meant that the methods were not equivalent.

\section{RESULTS AND DISCUSSION}

Grain yield has a low heritability in early generations (Bays, 1975). This can be overcome by the use of traits with strong heritability, which have a high association with grain yield. Among these characters, number of days to flowering and maturation and plant height at flowering and maturation, can be mentioned. In our work, the higher number of correlations among these traits and grain yield were significant (Table 2). Positive and significant correlations among these characters also were found for different authors (Weatherspoon and Went, 1934; Weiss et al., 1947; Johnson et al., 1955; Anand and Torrie, 1963; Kwon and Torrie, 1964; Harrison et al., 1981).

Soybean is one of the cultivated species which is most sensitive to photoperiod. Usually the cultivars are adapted to an area with a narrow latitude range and they are sensitive to changes in the sowing date (Kiihl and Garcia, 1989). The $\mathrm{F}_{3}$ generation was sown later than the $\mathrm{F}_{4}$ generation. This resulted in the $F_{3}$ populations in a smaller number of days to flowering and maturation and smaller plant height at flowering and maturation (Tables 3 and 4). 
Table 2 - Correlation estimates among traits assessed in 16 soybean populations in the $\mathrm{F}_{3}$ (diagonal above) and $\mathrm{F}_{4}$ generations (diagonal bellow) obtained by advancing from the $\mathrm{F}_{2}$ by the SPD and the SPDS methods. Data from 1997/98 and 1998/99, respectively ${ }^{\mathrm{a}}$.

\begin{tabular}{|c|c|c|c|c|c|}
\hline & & PHF & NDF & PHM & NDM \\
\hline \multirow[t]{2}{*}{ PHF } & SPD & - & $0.69 * *$ & $0.71^{* *}$ & $0.36^{*}$ \\
\hline & SPDS & - & $0.74 * *$ & $0.65^{* *}$ & $0.31 *$ \\
\hline \multirow[t]{2}{*}{ NDF } & SPD & $0.52 * *$ & - & $0.55^{* *}$ & $0.22 *$ \\
\hline & SPDS & $0.64 * *$ & - & $0.68^{* *}$ & $0.18^{\mathrm{ns}}$ \\
\hline \multirow[t]{2}{*}{ PHM } & SPD & $0.62 * *$ & $0.39 *$ & - & $0.29 *$ \\
\hline & SPDS & $0.69 * *$ & $0.54 * *$ & - & $0.41 * *$ \\
\hline \multirow[t]{2}{*}{ NDM } & SPD & $0.57 * *$ & $0.47 * *$ & $0.50 * *$ & - \\
\hline & SPDS & $0.48 * *$ & $0.39 *$ & $0.33^{*}$ & - \\
\hline \multirow[t]{2}{*}{ IPY $^{\mathbf{b}}$} & SPD & $0.22 *$ & $0.10^{\mathrm{ns}}$ & $0.23 *$ & $0.21 *$ \\
\hline & SPDS & $0.36^{*}$ & $0.19^{\mathrm{ns}}$ & $0.35^{*}$ & $0.37 *$ \\
\hline
\end{tabular}

a PHF: plant height at flowering; NDF: number of days to flowering; PHM: plant height at maturity; NDM: number of days to maturity; IPY: individual plant yield.

${ }^{b}$ assessed in seven populations in the $\mathrm{F}_{4}$ generation.

$*$ and ** indicate significance at $\mathrm{P}<0.05$ and $\mathrm{P}<0.01$ by $t$ test, respectively.

When both methods are compared, the results of the coefficients of variation (Tables 3, 4 and 5) showed that the selection done in the $\mathrm{F}_{2}$ generation did not affect the variability. The populations conducted by the SPDS method, which suffered a strong selection in the $\mathrm{F}_{2}$ generation, continued showing values close to the variation in the populations obtained through the SPD method, which did not suffer any selection. According to Allard (1960), in most hybrids a great number of genes segregate, and thus, each $F_{2}$ plant was different from all the others. This fact explained the maintenance of the variation in the populations obtained by the SPDS method.

Averages of populations obtained by the SPDS method for all characteristics evaluated were always superior to those obtained by the SPD method (Tables 3, 4 and 5). The only exception was for the NDM character in the $\mathrm{F}_{3}$ generation (Table 3), where the SPD method had a slightly superior average compared to the SPDS method (145.3 days for SPD and 144.1 days for SPDS).

For IPY trait, evaluated only in the $\mathrm{F}_{4}$ generation, the comparison was only possible in populations where the cross-breeding involved early parents. Populations where the cycle was too long suffered a strong bug attack (Nezara viridula), which made it impossible to evaluate the IPY in these populations. Hence IPY was evaluated in seven populations (Table 5).

Table 3 - Means and coefficients of variation (cv) for four traits in 16 populations in the $\mathrm{F}_{3}$ generation obtained by advancing from the $\mathrm{F}_{2}$ by the SPD and the SPDS methods. Data from 1997/98 .

\begin{tabular}{|c|c|c|c|c|c|c|c|c|c|c|c|c|c|c|c|c|}
\hline \multirow[b]{3}{*}{ population } & \multicolumn{4}{|c|}{ PHF } & \multicolumn{4}{|c|}{ NDF } & \multicolumn{4}{|c|}{ PHM } & \multicolumn{4}{|c|}{ NDM } \\
\hline & \multicolumn{2}{|l|}{ SPD } & \multicolumn{2}{|c|}{ SPDS } & \multicolumn{2}{|c|}{$\begin{array}{l}\text { SPD } \\
\end{array}$} & \multicolumn{2}{|c|}{ SPDS } & \multicolumn{2}{|c|}{ SPD } & \multicolumn{2}{|c|}{ SPDS } & \multicolumn{2}{|c|}{ SPD } & \multicolumn{2}{|c|}{ SPDS } \\
\hline & mean & $\mathrm{cV}$ & mean & $\mathrm{cv}$ & mean & $\mathrm{cv}$ & mean & $\mathrm{cV}$ & mean & $\mathrm{cV}$ & mean & $\mathrm{cV}$ & mean & $\mathrm{cV}$ & mean & $\mathrm{cV}$ \\
\hline 1 & 23.1 & 30.7 & 25.8 & 31.8 & 49.7 & 12.7 & 54.0 & 25.2 & 28.5 & 30.5 & 26.7 & 30.7 & 135.8 & 3.8 & 136.2 & 8.6 \\
\hline 2 & 23.5 & 32.3 & 37.0 & 24.1 & 49.6 & 12.5 & 62.0 & 7.7 & 28.8 & 34.7 & 40.8 & 18.6 & 146.0 & 4.2 & 145.8 & 3.9 \\
\hline 3 & 31.2 & 19.9 & 33.9 & 20.4 & 54.4 & 13.1 & 59.0 & 8.6 & 37.7 & 26.5 & 39.8 & 22.4 & 143.5 & 5.2 & 146.0 & 3.3 \\
\hline 4 & 34.7 & 28.5 & 36.2 & 23.2 & 57.9 & 10.5 & 57.0 & 13.0 & 43.1 & 36.4 & 40.6 & 16.5 & 134.0 & 4.4 & 136.5 & 5.3 \\
\hline 5 & 25.2 & 35.7 & 35.8 & 32.4 & 49.2 & 14.8 & 61.0 & 17.5 & 30.7 & 29.0 & 53.2 & 16.4 & 140.8 & 5.1 & 148.7 & 6.5 \\
\hline 6 & 31.4 & 43.3 & 33.8 & 29.0 & 51.8 & 14.5 & 58.0 & 15.0 & 40.0 & 32.7 & 43.4 & 35.7 & 148.2 & 5.1 & 147.2 & 5.5 \\
\hline 7 & 23.9 & 34.3 & 21.7 & 38 & 48.8 & 18.2 & 53.0 & 21.3 & 27.7 & 36.1 & 28.0 & 28 & 147.7 & 5.9 & 141.9 & 7.6 \\
\hline 8 & 28.5 & 32.6 & 42.2 & 20.9 & 53.6 & 12.5 & 62.0 & 8.4 & 33.8 & 30.8 & 53.7 & 21.4 & 135.5 & 4.9 & 136.3 & 3.7 \\
\hline 9 & 28.5 & 35.4 & 41.8 & 20.6 & 53.7 & 13.6 & 55.0 & 17.6 & 39.3 & 23.4 & 54.7 & 23.0 & 153.0 & 5.2 & 156.0 & 4.6 \\
\hline 10 & 25.8 & 18.6 & 34.3 & 29.7 & 53.2 & 6.0 & 53.0 & 11.1 & 36.1 & 25.2 & 41.4 & 33.1 & 155.0 & 2.6 & 148.3 & 6.9 \\
\hline 11 & 31.5 & 30.8 & 34.5 & 29. & 50.0 & 16.0 & 56.0 & 20.7 & 42.7 & 32.8 & 38.0 & 25 & 147.5 & 4.8 & 140.6 & 3.4 \\
\hline 12 & 22.0 & 19.1 & 21.7 & 14.8 & 51.4 & 6.6 & 50.0 & 6. & 21.6 & 29.2 & 22.1 & 15 & 145.8 & 2.0 & 135.8 & 9.1 \\
\hline 13 & 24.0 & 30.4 & 28.6 & 23.4 & 56.0 & 10.9 & 53.3 & 5.3 & 28.4 & 27.1 & 32.6 & 23.6 & 149.1 & 3.8 & 148.2 & 2.0 \\
\hline 14 & 31.8 & 34.0 & 29.5 & 40.7 & 54.8 & 16.2 & 57.4 & 13.1 & 34.3 & 25.1 & 37.2 & 33.6 & 154.0 & 5.9 & 154.7 & 1.2 \\
\hline 15 & 36.9 & 20.1 & 36.2 & 24.6 & 59.6 & 11.2 & 61.7 & 10.5 & 38.5 & 26.0 & 41.2 & 21.8 & 155.1 & 4.5 & 148.7 & 5.6 \\
\hline 16 & 15.5 & 26.4 & 20 & 19.5 & 47.5 & 16.4 & 46.7 & 15.2 & 18.9 & 17.5 & 19.8 & 22.7 & 134.2 & 5.6 & 136.0 & 5.1 \\
\hline Means & 27.3 & 29.6 & 32.0 & 26.4 & 52.5 & 12.9 & 56.1 & 13.5 & 33.1 & 28.9 & 39.1 & 24.4 & 145.3 & 4.6 & 144.1 & 5.1 \\
\hline
\end{tabular}

${ }^{a}$ PHF: plant height $(\mathrm{cm})$ at flowering; NDF: number of days to flowering; PHM: plant height $(\mathrm{cm})$ at maturity; NDM: number of days to maturity. Number of individuals assessed in each population $(\mathrm{N})=60$ for SPD method and 20 for SPDS method. 
Table 4 - Means and coefficients of variation (cv) for four traits in 16 populations in the $\mathrm{F}_{4}$ generation obtained by advancing from the $F_{2}$ by the SPD and the SPDS methods. Data from 1998/99 .

\begin{tabular}{|c|c|c|c|c|c|c|c|c|c|c|c|c|c|c|c|c|}
\hline & \multicolumn{4}{|c|}{ PHF } & \multicolumn{4}{|c|}{ NDF } & \multicolumn{4}{|c|}{ PHM } & \multicolumn{4}{|c|}{ NDM } \\
\hline & \multicolumn{2}{|c|}{ SPD } & \multicolumn{2}{|c|}{ SPDS } & \multicolumn{2}{|c|}{ SPD } & \multicolumn{2}{|c|}{ SPDS } & \multicolumn{2}{|c|}{ SPD } & \multicolumn{2}{|c|}{ SPDS } & \multicolumn{2}{|c|}{ SPD } & \multicolumn{2}{|c|}{ SPDS } \\
\hline Population & mean & cv & mean & cv & mean & cv & mean & cv & mean & cv & mean & cv & mean & cv & mean & cv \\
\hline 1 & 30.1 & 22.6 & 40.8 & 12.5 & 53.0 & 9.4 & 57.8 & 5.9 & 43.3 & 29.3 & 47.0 & 16.0 & 141.0 & 8.2 & 42.6 & 5.2 \\
\hline 2 & 35.1 & 22.2 & 44.0 & 13.2 & 56.7 & 13.8 & 64.9 & 8.5 & 42.4 & 33.0 & 55.0 & 21.8 & 139.0 & 2.3 & 149.3 & 9.4 \\
\hline 3 & 41.7 & 16.5 & 49.1 & 22.0 & 61.4 & 7.7 & 63.8 & 11.8 & 48.9 & 31.5 & 53.8 & 24.3 & 145.7 & 4.5 & 161.1 & 4.8 \\
\hline 4 & 41.8 & 17.2 & 45.5 & 25.1 & 64.0 & 7.7 & 59.5 & 11.1 & 48.3 & 21.7 & 48.4 & 18.6 & 148.3 & 3.6 & 146.0 & 5.4 \\
\hline 5 & 41.4 & 15.0 & 42.0 & 15.2 & 64.0 & 8.6 & 61.9 & 4.4 & 43.6 & 28.7 & 44.2 & 10.6 & 155.0 & 3.9 & 153.0 & 1.3 \\
\hline 6 & 38.8 & 21.9 & 50.8 & 12.2 & 59.8 & 14.7 & 63.4 & 5.8 & 43.0 & 25.3 & 60.2 & 10.1 & 149.0 & 5.7 & 168.0 & 1.3 \\
\hline 7 & 57.0 & 14.7 & 59.3 & 8.6 & 63.7 & 7.1 & 67.1 & 3.9 & 47.3 & 27.9 & 47.6 & 38.4 & 153.0 & 6.9 & 163.9 & 3.8 \\
\hline 8 & 45.1 & 19.7 & 64.1 & 6.7 & 62.7 & 12.4 & 67.2 & 5.6 & 47.8 & 17.8 & 61.5 & 18.0 & 154.4 & 7.1 & 168.0 & 3.2 \\
\hline 9 & 46.9 & 16.6 & 57.5 & 13.2 & 58.0 & 2.4 & 66.9 & 3.3 & 50.5 & 18.2 & 54.6 & 13.6 & 162.3 & 5.2 & 168.0 & 1.8 \\
\hline 10 & 50.6 & 18.0 & 60.2 & 13.6 & 64.3 & 8.6 & 63.6 & 10.5 & 53.5 & 11.2 & 59.6 & 13.9 & 163.6 & 4.0 & 164.0 & 4.5 \\
\hline 11 & 55.4 & 12.8 & 57.1 & 10.5 & 62.0 & 8.4 & 63.4 & 3.6 & 63.5 & 14.6 & 70.2 & 16.1 & 164.9 & 4.1 & 152.2 & 1.2 \\
\hline 12 & 32.4 & 17.9 & 29.8 & 18.1 & 55.9 & 9.8 & 57.8 & 7.3 & 35.0 & 10.0 & 38.0 & 19.5 & 155.0 & 1.1 & 165.5 & 3.1 \\
\hline 13 & 35.2 & 4.3 & 34.4 & 18.3 & 63.1 & 1.7 & 56.7 & 2.5 & 38.3 & 17.5 & 39.3 & 20.9 & 160.6 & 4.1 & 164.0 & 3.8 \\
\hline 14 & 24.4 & 9.4 & 25.7 & 14.8 & 62.0 & 5.6 & 59.8 & 9.4 & 26.3 & 24.7 & 27.2 & 7.7 & 150.3 & 3.8 & 155.8 & 1.2 \\
\hline 15 & 26.2 & 29.4 & 23.6 & 22.5 & 60.7 & 5.8 & 57.3 & 8.7 & 24.6 & 35.8 & 30.2 & 66.5 & 150.8 & 7.6 & 151.0 & 5.4 \\
\hline 16 & 19.8 & 22.7 & 23.2 & 12.1 & 54.6 & 13.6 & 49.5 & 11.9 & 22.9 & 26.6 & 26.2 & 16.8 & 135.8 & 4.0 & 140.8 & 6.6 \\
\hline Means & 38.9 & 17.6 & 44.2 & 14.9 & 60.4 & 8.6 & 61.3 & 7.1 & 42.4 & 23.4 & 47.7 & 20.8 & 151.8 & 4.7 & 157.0 & 4.0 \\
\hline
\end{tabular}

${ }^{a}$ PHF: plant height $(\mathrm{cm})$ at flowering; NDF: number of days to flowering; PHM: plant height $(\mathrm{cm})$ at maturity; NDM: number of days to maturity. Number of individuals assessed in each population $(\mathrm{N})=50$ for SPD method and 10 for SPDS method.

Table 5 - Means and coefficients of variation (cv) for individual plant yield (in grams) in seven populations in the $\mathrm{F}_{4}$ generation, obtained by advancing from the $\mathrm{F}_{2}$ by the SPD and the SPDS methods. Data from 1998/99a.

\begin{tabular}{|c|c|c|c|c|}
\hline \multirow{3}{*}{ Population } & \multicolumn{4}{|c|}{ Weight } \\
\hline & \multicolumn{2}{|c|}{ SPD } & \multicolumn{2}{|c|}{ SPDS } \\
\hline & mean & cv & mean & cv \\
\hline 1 & 12.4 & 68.15 & 19.57 & 47.37 \\
\hline 2 & 11.87 & 26.62 & 14.01 & 94.22 \\
\hline 3 & 5.95 & 17.98 & 6.49 & 39.45 \\
\hline 4 & 6.00 & 57.33 & 6.30 & 80.63 \\
\hline 11 & 1.34 & 42.54 & 1.63 & 29.45 \\
\hline 14 & 3.50 & 42.29 & 3.57 & 54.90 \\
\hline 16 & 3.94 & 75.13 & 4.18 & 77.51 \\
\hline Means & 6.42 & 47.15 & 7.96 & 60.50 \\
\hline
\end{tabular}

Taking into consideration all average values, 6.42 grams per plant was obtained by the SPD method against 7.96 grams obtained by the SPDS. As appeared from the coefficients of variation of 47.15 for SPD and 60.50 for SPDS, variation was not reduced by SPDS.
The statistical analysis showed that all regressions were significant and $\mathrm{R}^{2}$ values were very high, which meant that the linear equations explained the results obtained (Table 6). For the NDM trait in generation $\mathrm{F}_{3}$ (average of 145.3 days in SPD and 144.1 in SPDS) and NDF in generation $\mathrm{F}_{4}$ (60.4 days in SPD and 61.3 in SPDS), the means were too close. In these cases, the $t$-test considered that the $\beta$ equation values corresponded to one. In other words, it did not show significant differences and the two methods yielded equivalent mean values. For the NDF, PHF and PHM traits from $\mathrm{F}_{3}$ generation (Table 3) and PHF, NDM, PHM (Table 4) and IPY (Table 5) from $\mathrm{F}_{4}$ generation, where the means had bigger differences, the test rejected the hypothesis $\mathrm{H}_{0}: \beta=1$. This meant that the methods were not equivalent. As in these cases, the populations obtained by the SPDS method yielded superior means compared to those obtained by the SPD method, the substitution of the SPD by the SPDS method was recommended. These results supported the procedure used in the breeding program by the National Center for Soybean Research of EMBRAPA. 
Table 6 - Linear regression equations with respective determination coefficients and $\boldsymbol{t}$-values for testing $\mathrm{H}_{0}$ : $\beta=1$ against $\mathrm{H}_{1}: \beta<1$ for the NDF, PHF, NDM and PHM traits in the $\mathrm{F}_{3}$ and $\mathrm{F}_{4}$ generations and IPY in the $\mathrm{F}_{4}$ generation ${ }^{\mathrm{a}}$.

\begin{tabular}{|c|c|c|c|c|}
\hline Generation & Trait & Equation & $\mathbf{R}^{2}$ & $t$-values \\
\hline \multirow{4}{*}{$\mathrm{F}_{3}$} & $\mathrm{NDF}$ & $\mathrm{SPD}=0.932 \mathrm{SPDS} * *$ & 0.994 & $t=-3.55^{*}(\mathrm{~b})$ \\
\hline & PHF & $\mathrm{SPD}=0.838 \mathrm{SPDS} * *$ & 0.971 & $\boldsymbol{t}=-4.30 *(\mathrm{~b})$ \\
\hline & NDM & $\mathrm{SPD}=1.008 \mathrm{SPDS} * *$ & 0.999 & $t=+0.93^{\mathrm{ns}(\mathrm{b})}$ \\
\hline & PHM & $\mathrm{SPD}=0.837 \mathrm{SPDS} * *$ & 0.961 & $t=-3.74 *(\mathrm{~b})$ \\
\hline \multirow{5}{*}{$\mathrm{F}_{4}$} & $\mathrm{NDF}$ & $\mathrm{SPD}=0.981 \mathrm{SPDS} * *$ & 0.995 & $\boldsymbol{t}=-1.01^{\mathrm{ns}(\mathrm{b})}$ \\
\hline & PHF & $\mathrm{SPD}=0.866 \mathrm{SPDS} * *$ & 0.985 & $t=-4.85 *(b)$ \\
\hline & NDM & $\mathrm{SPD}=0.965 \mathrm{SPDS} * *$ & 0.997 & $t=-2.83 *(\mathrm{~b})$ \\
\hline & PHM & $\mathrm{SPD}=0.883 \mathrm{SPDS} * *$ & 0.990 & $t=-5.14 *(\mathrm{~b})$ \\
\hline & IPY & $\mathrm{SPD}=0.744 \mathrm{SPDS} * *$ & 0.972 & $\boldsymbol{t}=-4.94 *(\mathrm{c})$ \\
\hline
\end{tabular}

a PHF: plant height $(\mathrm{cm})$ at flowering; NDF: number of days to flowering; PHM: plant height $(\mathrm{cm})$ at maturity; NDM: number of days to maturity; IPY: individual plant yield $(\mathrm{g})$

${ }^{\mathrm{b}} \boldsymbol{t}_{(0,05 ; 15)}=1,75$ (one-tailed test)

${ }^{\mathrm{c}} \boldsymbol{t}_{(0,05 ; 6)}=1,94$ (one-tailed test)

** significant at the $1 \%$ level of probability.

This procedure has been efficient in conducting segregating populations for the development of new cultivars with long juvenile period, based on the SPDS method in the F2 generation (Kiihl and Garcia, 1989).

SPD and SPDS methods are modifications of the SSD method, and they both allow the fast advancement of generations, making it possible to obtain two generations per year (Kiihl and Garcia (1989). Boerma and Cooper (1975) compared the SSD method with the pedigree and the early generation test methods, these two with selection in the $F_{2}$ generation. The authors observed that the SSD method was the most efficient since it was fast in the advancement of generations and required less effort in the selection process. In this method, the selection is accomplished only in advanced generations, when it is more efficient. The methodology used in our work showed that although there was a selection in generation $F_{2}$ with SPDS method, it did not demand great efforts as in the pedigree and the early generation test methods. The SPDS method allowed the use of smaller population sizes. It reduced labor, breeder's work and experimental area in comparison to the SPD method.

\section{CONCLUSIONS}

The populations produced by SPDS tended to have higher means than those produced by SPD. The SPDS method maintained a fenotipic variation comparable to that of the SPD method, even when selection for high heritability traits correlated with grain yield was practiced in the $F_{2}$ generation. Thus it was possible to replace the SPD method by the SPDS method in soybean breeding.

\section{ACKNOWLEDGEMENTS}

The authors thank CNPq and CAPES for grants and financial support.

\section{RESUMO}

Este trabalho objetivou comparar os métodos de avanço de gerações segregantes SPD (vagem única por planta) e SPDS (vagem única por planta selecionada) no melhoramento da soja. Foram utilizadas 16 populações oriundas de cruzamentos de genótipos japoneses com brasileiros adaptados. Os caracteres número de dias para o florescimento (NDF) e para maturação (NDM), altura da planta no florescimento (PHF) e na maturação (PHM) e produtividade por planta individual (IPY) foram avaliados. As populações obtidas pelo método SPDS continuaram a apresentar valores de variabilidade próximos aos das populações obtidas pelo método SPD. A regressão linear (reta passando pela origem) mostrou que para NDM na geração $F_{3}$ e NDF na geração $F_{4}$, os métodos são equivalentes. Para as demais combinações caracteres/gerações, o SPDS produziu maiores médias. O método SPDS permite 
o avanço de gerações com populações de menor tamanho comparado ao SPD, além de proporcionar ganho genético.

\section{REFERENCES}

Allard, R. W. (1960), Principles of plant breeding. John Wiley and Sons, New York.

Anand, S. C. and Torrie, J. H. (1963), Heritability of yield and other traits and interrelationships among traits in the $\mathrm{F}_{3}$ and $\mathrm{F}_{4}$ generation of three soybean crosses. Crop Science, 3, 508-511.

Bays, I. A. (1975), Heritability and association of several quantitative characters in segregating populations of soybeans [Glycine $\max$ (L.) Merrill]. PhD Thesis, Mississipi State University, Mississipi, USA.

Boerma, H. R. and Cooper, R. L. (1975), Comparison of three selection procedures for yield in soybeans. Crop Science, 15, 225-229.

Brim, C. A. (1966), A modified pedigree method of selection in soybeans. Crop Science, 6, 20.

Bussab, W. 0. (1990), Modelos Especiais. In: Análise de variância e de regressão. São Paulo : Atlas. pp.73-81.

Destro, D.; Guerra, E. P.; Vello, E. P. and Moreira, L. M. (1994), Melhoramento genético da soja com sementes grandes. Revista Brasileira de Genética (Supplement), 17, 336.

Fehr, W. R. (1987), Soybean. In: Fehr, W. R. (ed.). Principles of cultivar development, v. 2. New York : Macmillan Publishing. pp. 533-576.

Fehr, W. R. and Caviness, C. E. (1977), Stages of soybean development. Iowa State University. Special Report 80. 12 pp.

Guerra, E. P.; Destro, D.; Miranda, L. A. and Montalván, R. (1999), Performance of food-type genotypes and their possibility for adaptation to Brazilian latitudes. Pesquisa Agropecuária Brasileira, 34, 575-583.

Harrison, S. A.; Boerma, H. B. and Ashley, D. A. (1981), Heritability of canopy-apparent photosynthesis and its relationship to seed yield in soybeans. Crop Science, 21, 222-226.

Johnson, H. W.; Robinson, H. F. and Comstock, R. F. (1955), Estimates of genetic and environmental variability in soybeans. Agronomy Journal, 47, 313-314.

Kiihl, R. A. S. and Garcia, A. (1989), The use of long juvenile trait in breeding soybean cultivars. Paper presented at $4^{\text {th }}$ Conferencia Mundial de Investigación en Soja, Buenos Aires, Argentina.

Kwon, S. H. and Torrie, J. H. (1964), Heritability and interrelationships among traits of two soybean populations. Crop Science, 4, 196-198.
Mannfredini, E.; Destro, D.; Homechin, M.; Sachsida, G. and Miglioranza, E. (1998), Alternatives to sowing vegetable types soybeans. Brazilian Archives of Biology and Technology, 41, 429-436.

Mode, J. C. and Robinson, H. F. (1959), Pleiotropism and genetic variance and covariance. Biometrics, $\mathbf{1 5}$, 518-537.

Marega Filho, M.; Destro, D.; Miranda, L. A.; Spinosa, W. A.; Carrão-Panizzi, M. C.; Montalván, R. (2001), Relationships among oil content, protein content and seed size in soybeans. Brazilian Archives of Biology and Technology, 44, 23-32.

Toledo, J. F. F.; Almeida, L. A.; Kiihl, R. A. S.; Carrão-Panizzi, M. C.; Kaster, M.; Miranda, L. C. and Menosso, O. G. (1994), Genetics and breeding. In: Tropical Soybean: Improvement and Production. Food Agriculture Organization of the United Nations, Rome. pp. 19-36.

Venkovsky, R. and Barriga P. (1992), Genética biométrica no fitomelhoramento. Sociedade Brasileira de Genética, Ribeirão Preto.

Weatherspoon, J. H. and Wentz, J. B. (1934), A statistical analysis of yield factors in soybeans. Agronomy Journal, 26, 524-531.

Weiss, M. G.; Weber, C. R. and Kalton, R. R. (1947), Early generation testing in soybeans. Agronomy Journal, 39, 791-811. 